\title{
Forewarning Bankruptcy: An Indigenous Model for Pakistan
}

\begin{abstract}
Muhammad Shahzad Ijaz', Ahmed Imran Hunjra², Rauf I Azam ${ }^{3}$
Abstract

Predicting financial health of enterprises is crucial for companies and banks (who lend money to them), as well as to all stakeholders. State Bank of Pakistan (SBP) has taken measures to implement Basel Accord framework for minimizing credit risk since its implementation in 2005. In this regard, there was a need for the development of corporate financial distress and bankruptcy prediction model which is specific to Pakistani companies to serve as a reliable tool for the assessment of financial health. In this paper we have proposed a model after a comprehensive analysis for objective prediction of financial health of companies. The proposed model has been tested for a sample of one hundred companies from non-financial sector of PSX listed companies, among which fifty were bankrupt and fifty financially healthy. Twenty-nine financial and accounting variables were used as input to model development procedure. The results suggest that the proposed model is capable of making a correct forecast of financial health of these companies.
\end{abstract}

Keywords: PSX, Financial distress, Bankruptcy prediction, Financial ratios,

JEL Classification: C53, M41, G33

\section{Introduction}

Financial distress is a situation in which amounts are due on business to their creditors are prolonged, and are not paid out timely and it leads to bankruptcy of company which may lead the companies to the final declaration of economic failure know as bankruptcy. In the words of Beaver (1966) and Altman (1993), business failure is a state when an enterprise is not able to meet its monetary commitment as it matures. All stakeholders of the company remain interested in reliable predictive

1 MS Scholar, UIMS-PMAS-University of Arid Agriculture Rawalpindi, Pakistan. Email: ms.ijaaz@ gmail.com

2 Post-Doctoral Fellow, School of Accounting, Finance and Economics, The University of Waikato, Hamilton, New Zealand E Assistant Professor, UIMS-PMAS-Arid Agriculture University Rawalpindi, Pakistan

3 Vice Chancellor, University of Education, Lahore, Pakistan

\begin{tabular}{lll} 
ARTICLE HISTORY \\
\hline 9 Jul, 2017 Submission Received & 11 Aug, 2017 & First Review \\
\hline 19 Aug, 2017 Revised Version Received & 23 Sep, 2017 & Second Review \\
\hline 15 Oct, 2017 Revised Version Received & 10 Nov, 2017 & Accepted
\end{tabular}


models to forecast the risks of business failure. Continuously changing business practices demand indigenous model for credit risk assessment. So, a model that can provide a correct and timely forecast of business failure would be quite useful for stakeholders of a company in determining their strategy and future course of action.

Early warning models (e.g. Altman, 1968; Deakin, 1972; Ohlson, 1980) provide the company with a powerful helping tool to identify and manage the supplier firms' bankruptcy and to prevent crises in their procurement (Harlan \& Marjorie, 2002). Moreover, stakeholders of a company, like suppliers, investors and creditors, are interested in its ability to effectively meet future financial obligations. Failing to pay any liability may be a representative of financial distress and may raise the likelihood of bankruptcy for the company. Employees are interested in their job security and stability in the company and management is interested in knowing what problems they are about to face (Eidleman, 1995). Answers to all these concerns lie in a timely and accurate prediction of a company's financial health.

Financial distress and bankruptcy often complement each other in business environment and exists around the globe especially in developing countries. Over the last few years, firms in Pakistan have financially failed at higher rate (Hasnain \& Shah, 2011; $\mathrm{SECP}^{4}$ ) and others may fail in future, prompting some parties in the business community to call for government intervention, specifically by reforming insolvency law. The negative impacts of these events are affecting the social and economic areas of the country. Reason of failure for Pakistani companies might be global financial crisis, terrorism and security threats, power shortage and political instability. Newton (2009) stated that reasons behind the corporate bankruptcy are different across countries due to dissimilarities in accounting practices, social, political and economic environment and diverse capital structure. In order to prevent additional corporate failure and huge cost of bankruptcy, proper warning signals should be employed to predict the financial health of corporate sector.

Although one can expect that the independent auditors or other decision-makers are able to make correct assessment of a company's financial conditions, but studies have shown that, in practice, the assessments by auditors and decision makers do not perform well as compared to failure prediction models in making classification of failed company (Altman and Saunders, 1998). It is worth to note that about one-quarter of all defaulting issues were originally rated as investment grade by the professional rating agencies (Altman and Hotchkiss, 2006). Therefore, there is a need of investigation that which ratios best predict the corporate failure correctly and to develop prediction model to help banks, financial and non-financial institutions to forecast failure in

4 Background of the committee to review Corporate Rehabilitation Act. Retrieved from http://www. secp.gov.pk/news/pdf/news_09/cra_comite_bkgrnd.pdf 
the corporate sector of Pakistan. Hence, development of a failure prediction model specific to Pakistan is crucial to keep the corporate stakeholders safe from such loss.

Moreover, Altman's Z-Score (1968) model is constantly adjusted and modified to cater to the needs of specific industries and domestic environments in which research studies are conducted. These variants of Z-Score model have proven to be reliable tools for failure prediction in their respective contexts and business environments. However, because this widely used model, was originally developed on the basis of data from the developed economy of United States and may not be equally effective in a developing economy like Pakistan. Therefore, we find it worthwhile to look into the possibility of a modified model and its applicability in less developed / developing country.

Many previous studies (Wang \& Capmbell, 2010; Sori \& Jalil, 2009) used delisted companies as a proxy for bankrupt companies). This criterion does not suffice the requirement because corporations might delist themselves voluntarily form stock exchange as a part of their strategy for example events of buy back of share and violation of listing regulations also result in delisting. So, delisting of a company may not be taken as equivalent to an incident of bankruptcy. Another proxy for bankrupt companies might be the negative book value of equity or negative operating cash flows. It is not necessary that later situation prolongs, there might be a possibility that a company can incur losses in any single year and may be profitable next year. Therefore, we think that the negative book value of equity is the appropriate variable which can be used as the proxy for bankruptcy. Shareholders' equity shown in the balance sheet of a company, calculated by deducting total liabilities from total assets, shows that what is left with shareholders of the company. Its negative value shows that the shareholders of the company are left with nothing and are insolvent.

New model is useful in many ways. Analogous to banks who calculate probabilities of default (PD) for lending purposes; Corporations deal with risky customers and sell goods to them. Corporate account receivable managers calculate the repayment estimates and bad debts to ensure the safety of their loans. Developed model may assist the account receivable managers by assessing the financial health of their customers and in future decisions relating to them. The determination of PDs is important for investment bonds and loans. Therefore, investor should undertake default risk analysis and developed model in this study will enable investors to select good securities.

After having discussed the economic significance of predicting financial distress, this study focuses on the development of bankruptcy prediction model in Pakistan. This study is an effort to identify the best financial and accounting variables which preeminently discriminate bankrupt companies form non-bankrupt companies, to 
develop Z-Score model through a procedure identical to that of Altman's (1968) using multivariate statistical technique of discriminant analysis and logit model to provide a reliable tool as Internal rating bases (IRB) model in Pakistani context to banking industry for the credit evaluation of corporate loan applicants.

\section{Literature Review}

Previous bankruptcy studies have identified that financial ratios of the bankrupt companies are important in predicting bankruptcy (Altman, 1983; Agarwala \& Taffler, 2008; Tinoco \& Wilson, 2013). According to Chye, Hye, Meng and Meng (1989), financial ratios can provide a good overview of strengths and weaknesses of a firm. They also reflect performance and indicate trends.

Beaver (1966) was the ever first researchers who suggested a model to predict business failure. He tested the predictive ability of financial ratios to determine failure on a univariate basis. Sample of the study consisted of 79 companies from Moody's Industrial Manual which were failed during 1954 to 1964, from 38 different industries. He presented the evidence that profitability ratios are good predictor of bankruptcy. It can provide signals of failure of the company in advance. Further, he explored that some ratios have better predictive powers than others.

After two years, Altman used Multiple Discriminant Analysis (MDA) and predicted the relationship of bankruptcy, using a dichotomous response variable, with independent predictors of accounting ratios. Financial ratios were extracted from the financial statements of sampled companies one year prior to bankruptcy to develop the bankruptcy prediction model. The developed model was $\mathrm{Z}=1.2 \mathrm{X}_{1}+1.4 \mathrm{X}_{2}+3.3$ $\mathrm{X}_{3}+0.6 \mathrm{X}_{4}+.999 \mathrm{X}_{5}$. Where, $\mathrm{X}_{1}$ was working capital to total assets, $\mathrm{X}_{2}$ was retained earnings to total assets, $\mathrm{X}_{3}$ was earnings before interest taxes to total assets, $\mathrm{X}_{4}$ was market value of equity to book value of total debt and $\mathrm{X}_{5}$ was sales to total assets. The model correctly classified the sampled companies with 95\% accuracy. After Beaver (1966) and Altman (1968), numerous studies (e.g. Libby, 1975; Dambolene \& Khoury, 1980; Coats \& Fant 1993) were conducted in the field of corporate bankruptcy and the company closed down. These researches were conducted to expand the statistical models for the prediction of bankrupt enterprises in other countries and proved that financial ratios have intrinsic capability of identifying failure.

Deakin (1972) suggested another model to predict corporate failure which was an alternate to the models of Altman and Beaver. Analysis of the failure of the company showed that the total debt of the companies was highly volatile. Cash flow and net income have relatively stable movements in two samples of failed and non-failed companies. The study stabbed to reduce the number of variable used in classification 
and as a result classification errors were significantly increased. Study recommended MDA technique to be useful forecast bankruptcy with higher accuracy even three years before actual failure. He used the Altman (1968) approach using all financial ratios used in Beaver's study and reported significant improvement in the prediction results.

The need was further recognized by the researchers and Edmister (1972) proposed his model for distress prediction in small business loans. Sample was consisted of guarantee receivers and borrower for the period 1954-1969 of small businesses. He analyzed 19 financial ratios, which had been proved significant in the past researches. Model achieved $93 \%$ accuracy with 100\% correct prediction of failed firms and $86 \%$ correct prediction of non-failed firms.

Westgaard and Wijst (2001) employed the logit approach in order to predict bankruptcies in the Norwegian business sector and find that the model is able to predict defaults sufficiently well. As determinants of default identified the ratios of liquidity, solvency, financial coverage as well as size and age to be statistically significant.

Gentry, Newbold and Whitford (1985) formed the model using several financial ratios and yielded better bankruptcy perdition. The findings of Ward and Foster (1997) suggested that the use of a dichotomous variable, healthy versus loan default as dependent variable in generating the prediction model provided a better measure than the bankruptcy dependent variable in terms of predicting the ability of firm to fulfill its obligations when due. Ward and Foster (1997) argued that the use of dichotomous variable and healthy versus loan default as a dependent variable had provided a better indicator for insolvency than bankruptcy and therefore was more consistent with the underlying theoretical explanations.

Abdullah, Halim, Ahmad and Rose (2008) compared three methods of predicting financially troubled companies in Malaysia, these were multiple discriminant analysis (MDA), hazard model and logistic regression analysis. 52 distressed and non-distressed companies were in the sample and result showed that hazard model correctly predicts $94.9 \%$ of the cases. The study provided a comparison of the approaches.

Studies (like Abdullah et al. 2008) evaluated more than one prediction model to forecast business failure. Muller, Bruwer and Hamman (2009) evaluated the effectiveness of four prediction models. Companies listed on Johannesburg Stock Exchange (JSE) were studied for the purpose. Their study concluded that multiple discriminant analysis and recursive partitioning using decision tree gave the highest prediction accuracy for failed firms. This was another important point that cost of wrong categorizing the failed firm was much higher to the investors as compared 
to the cost of wrong categorizing non failed firms. Logit and neural networks also predicted well with overall accuracy.

\subsection{Research model and hypothesis}

As discussed in literature, previous research studies provide various methods for the prediction of failing firms. Aziz and Dar (2006) ranked the 16 techniques, which have been used frequently in the bankruptcy prediction literature. After reviewing the 86 studies, the study concluded that multiple discriminant analysis is the number one and binary regression (logit analysis) is the second among sixteen techniques for developing a new bankruptcy prediction model used by the Altman's (1968) and Ohlson's (2010) were two best and efficient. This section explains the research model under both techniques.

Generic equation of discriminant model and logit is as follows

$\mathrm{Z}=$ Discriminant score $\quad \mathrm{W}_{\mathrm{n}}=$ Discriminant weight (coefficients)

$\mathrm{X}_{\mathrm{n}}=$ Discriminant variable (ratios)

$\mathrm{P}_{(\mathrm{z})}=$ Probability of bankruptcy

$$
P_{(z)}=\frac{1}{1+\mathrm{e}^{-\left(\mathrm{W}_{0}+\mathrm{W}_{1} \mathrm{X}_{1}+\ldots+\mathrm{W}_{\mathrm{n}} \mathrm{X}_{\mathrm{n}}\right)}}
$$

$\mathrm{W}_{\mathrm{n}}=$ Logit weight (coefficients)

$\mathrm{X}_{\mathrm{n}}=$ Logit variable (ratios)

Logit model uses Maximum Likelihood (ML) estimation and calculates the conditional probability of the firm to join bankrupt or non-bankrupt group. It represents the relationship of classifying variable which is in the form of 0 or 1 i.e., non-bankrupt or bankrupt, with $\mathrm{k}$ predictors $\mathrm{x}_{1}, \mathrm{x}_{2}, \mathrm{x}_{3} \ldots \mathrm{x}_{\mathrm{k}}$ of financial and accounting ratios. One crucial issue in logit analysis is the determination of cutoff point, and it is highly sensitive for the classification accuracy. In order to rank a company as a financially distressed or non-distressed, fitted probability using ML estimation is put side by side with the predetermined cutoff point. When binary variable consists of two groups e.g. non-bankrupt or bankrupt, a case will be classified as non-bankrupt if the fitted probability is less than cut off point and vice versa. Though, there are no clear rules for specifying the cutoff point but in the case of two group dependent variable, 0.5 probability is frequently used in the literature as cutoff point for classification accuracy (Wang \& Campbell, 2010; Madalina, Mugurel, \& Marin, 2009). So, a case is classified as non-bankrupt if its fitted probability is less than 0.5 . On the contrary, a case is classified as bankrupt if its fitted probability is greater than 0.5 . 
On the basis of previous literature of bankruptcy prediction, following statements are hypothesized.

$\mathrm{H}_{0}$ : Z-Score does not predict bankruptcy in Pakistan.

$\mathrm{H}_{\mathrm{A}}$ : Z-Score does predict bankruptcy on the basis of published financial information.

$\mathrm{H}_{0}$ : Logit does not predict bankruptcy in Pakistan.

$\mathrm{H}_{\mathrm{A}}$ : Logit does predict bankruptcy on the basis of published financial information.

\section{Methodology}

\subsection{Sample selection}

Balance Sheet Analysis (BSA) and annual report were the only source of data which can be used for the calculation of financial and accounting ratios for sampled firms. Population of the study comprises of all non-financial companies, which exclude banks and non-banking financial institutions, listed on PSX over the period 2010 to 2013. Next important step was to specify the criteria under which a company might be considered as failed one. This study uses negative book value of equity as proxy of bankruptcy, therefore a company was selected for bankrupt group if the book value of any company becomes negative in any year from 2010 to 2013.

Table 1: List of Bankrupt (Group I) and Non-Bankrupt Companies (Group II)

\begin{tabular}{|c|c|c|c|}
\hline Sr. No. & Bankrupt Companies & Non-Bankrupt Companies & Sector \\
\hline 1 & Annoor Textile Mills Ltd. & $\begin{array}{c}\text { Allawasaya Textile \& Finishing Mills } \\
\text { Ltd. }\end{array}$ & Textile \\
\hline 2 & Asim Textile Mills Ltd. & Ashfaq Textile Mills Ltd. & Textile \\
\hline 3 & Elahi Cotton Mills Ltd. & International Knitwear Ltd. & Textile \\
\hline 4 & Hajra Textile Mills Ltd. & Al-Qadir Textile Mills Ltd. & Textile \\
\hline 5 & Karim Cotton Mills Ltd. & Quetta Textile Mills Ltd. & Textile \\
\hline 6 & Nazir Cotton Mills Ltd. & Mukhtar Textile Mills Ltd. & Textile \\
\hline 7 & Fateh Sports Wear Ltd. & Aruj Garment Accessories Ltd. & Textile \\
\hline 8 & Noor Silk Mills Ltd. & Janana De Malucho Textile Mills & Textile \\
\hline 9 & Bawany Sugar Mills Ltd. & Mehran Sugar Mills Ltd. & Sugar \& Food \\
\hline 10 & Fecto Sugar Mills Ltd. & Faran Sugar Mills Ltd. & Sugar \& Food \\
\hline 11 & Mirza Sugar Mills Ltd. & Sanghar Sugar Mills Ltd. & Sugar \& Food \\
\hline
\end{tabular}




\begin{tabular}{|c|c|c|c|}
\hline 12 & Pangrio Sugar Mills Ltd. & Clover Pakistan Ltd. & Sugar \& Food \\
\hline 13 & Saleem Sugar Mills Ltd. & Punjab Oil Mills Ltd. & Sugar \& Food \\
\hline Sr. No. & Bankrupt Companies & Non-Bankrupt Companies & Sector \\
\hline 14 & Morafco Industries Ltd. & Habib - ADM Ltd & Sugar \& Food \\
\hline 15 & Shakarganj Food Ltd. & Adam Sugar Mills Ltd. & Sugar \& Food \\
\hline 16 & $\begin{array}{c}\text { Mandviwala Mauser Plastic } \\
\text { Industries Ltd. }\end{array}$ & Biafo Industries Ltd. & $\begin{array}{c}\text { Chemicals \& } \\
\text { Pharmaceuticals }\end{array}$ \\
\hline 17 & Fateh Industries Ltd. & Al-Khair Gadoon Ltd. & $\begin{array}{l}\text { Other Manufac- } \\
\text { turing n.e.s. }\end{array}$ \\
\hline 18 & $\begin{array}{l}\text { Dewan Automotive Engi- } \\
\text { neering Ltd. }\end{array}$ & Agriauto Industries Limited & $\begin{array}{c}\text { Motor Vehicles, } \\
\text { Trailers \& Auto- } \\
\text { parts }\end{array}$ \\
\hline 19 & $\begin{array}{l}\text { Pakistan International Air- } \\
\text { lines Corporation Ltd. }\end{array}$ & $\begin{array}{l}\text { Pakistan Telecommunication Com- } \\
\text { pany Ltd }\end{array}$ & $\begin{array}{c}\text { Information, } \\
\text { Comm. and } \\
\text { Transport Services }\end{array}$ \\
\hline 20 & Central Forest Products Ltd. & Pakistan Paper Products Ltd. & $\begin{array}{l}\text { Paper, Paperboard } \\
\text { \& Products }\end{array}$ \\
\hline 21 & $\begin{array}{c}\text { Dadabhoy Construction } \\
\text { Tech. Ltd. }\end{array}$ & Dreamworld Ltd. & $\begin{array}{c}\text { Other Services } \\
\text { Activities }\end{array}$ \\
\hline 22 & Accord Textiles Ltd. & Regent Textile Industries Ltd. & Textile \\
\hline 23 & Amin Spinning Mills Ltd. & Latif Jute Mills Ltd. & Textile \\
\hline 24 & Taj Textile Mills Ltd. & Blessed Textiles Ltd. & Textile \\
\hline 25 & Syed Match Company Ltd. & Goodluck Industries Ltd. & $\begin{array}{l}\text { Other Manufac- } \\
\text { turing n.e.s. }\end{array}$ \\
\hline 26 & Adil Textile Mills Ltd. & Saritow Spinning Mills Ltd. & Textile \\
\hline 27 & Brothers Textile Mills Ltd. & Sana Industries Ltd. & Textile \\
\hline 28 & Ghazi Fabrics Int. Ltd. & Fazal Textile Mills Ltd. & Textile \\
\hline 29 & Hamid Textile Mills Ltd. & Hala Enterprises Ltd. & Textile \\
\hline 30 & Khyber Textile Mills Ltd. & Globe Textile Mills (OE) Ltd. & Textile \\
\hline 31 & Mian Textile Industries Ltd. & Fateh Textile Mills Ltd & Textile \\
\hline 32 & Mubarak Textile Mills Ltd. & Sunrays Textile Mills Ltd. & Textile \\
\hline 33 & $\begin{array}{l}\text { Saleem Denim Industries } \\
\text { Ltd. }\end{array}$ & Bannu Woollen Mills Ltd. & Textile \\
\hline 34 & Sally Textile Mills Ltd. & Azam Textile Mills Ltd. & Textile \\
\hline 35 & Dewan Salman Fibre Ltd. & Dawood Hercules Chemicals Ltd. & $\begin{array}{c}\text { Chemicals \& } \\
\text { Pharmaceuticals }\end{array}$ \\
\hline
\end{tabular}




\begin{tabular}{|c|c|c|c|}
\hline 36 & Pakistan PVC Ltd. & Dynea Pakistan Ltd. & $\begin{array}{c}\text { Chemicals \& } \\
\text { Pharmaceuticals }\end{array}$ \\
\hline 37 & $\begin{array}{l}\text { Khyber Tobacco Company } \\
\text { Ltd. }\end{array}$ & Gillette Pakistan Ltd. & $\begin{array}{l}\text { Other Manufac- } \\
\text { turing n.e.s. }\end{array}$ \\
\hline 38 & MACPAC Films Ltd. & Dadex Eternit Ltd. & $\begin{array}{c}\text { Other Manufac- } \\
\text { turing n.e.s. }\end{array}$ \\
\hline 39 & $\begin{array}{l}\text { Dandot Cement Company } \\
\text { Ltd. }\end{array}$ & Cherat Cement Company Ltd. & $\begin{array}{c}\text { Other Non-Me- } \\
\text { tallic Products } \\
\text { Cement }\end{array}$ \\
\hline 40 & Balochistan Glass Ltd. & Karam Ceramics Ltd. & Mineral products \\
\hline 41 & $\begin{array}{c}\text { Transmission Engineering } \\
\text { Industries Ltd. } \\
\end{array}$ & Bela Automotives Ltd. & $\begin{array}{l}\text { Vehicles, Trailers } \\
\text { \& Semi-trailers }\end{array}$ \\
\hline 42 & Generteck Pakistan Ltd. & Shell Gas LPG (Pakistan) Ltd. & Fuel \& Energy \\
\hline 43 & $\begin{array}{c}\text { Japan Power Generation } \\
\text { Ltd. }\end{array}$ & Kohinoor Energy Ltd. & Fuel \& Energy \\
\hline 44 & Southern Networks Ltd. & Pak Datacom Ltd. & $\begin{array}{c}\text { Information, } \\
\text { Comm. and } \\
\text { Transport }\end{array}$ \\
\hline 45 & $\begin{array}{l}\text { Khurshid Spinning Mills } \\
\text { Ltd. }\end{array}$ & N.P. Spinning Mills Ltd. & Textile \\
\hline 46 & Kohinoor Mills Ltd. & Fatima Enterprises Ltd. & Textile \\
\hline 47 & $\begin{array}{l}\text { Mohammad Farooq Textile } \\
\text { Mills Ltd. }\end{array}$ & Bhanero Textile Mills Ltd. & Textile \\
\hline 48 & Taha Spinning Mills Ltd. & Safa Textiles Ltd. & Textile \\
\hline 49 & S.G. Fibres Ltd. & $\begin{array}{c}\text { Crescent Fibers Ltd. (Crescent } \\
\text { Boards Ltd.) }\end{array}$ & Textile \\
\hline 50 & $\begin{array}{c}\text { Zeal Pak Cement Factory } \\
\text { Ltd. }\end{array}$ & Fecto Cement Ltd & Cement \\
\hline
\end{tabular}

Source: Authors' compilation

Non-bankrupt companies were selected on the following criteria.

1. Book value of the equity is positive and company is running profitable business.

2. Company is from the same year as the company in the group I.

3. Company belongs to same sector.

4. Asset size of the company is close to the asset size of the companies in the group I.

Procedure of the selection of companies for non-failed group led the study to the 
paired sample design. This design is in line with the design of previous bankruptcy prediction studies.

\subsection{Data collection and computation of ratios}

Balance Sheet Analysis for the years 2010 to 2013 was used for data collection. Input ratios were selected on the basis of their frequent use in literature and their predictive power in previous studies. Data of fourteen Balance Sheet and Income Statement accounts were compiled for one hundred selected companies and relevant ratios were calculated.

\subsection{Correlation analysis}

Due to incorporating a large number of ratios in the analysis at initial stage, there was a likelihood of high degree of correlation or multi-collinearity among the study variables; (Altman 1968). The problem of high correlation between independent variables was a threat for successful implementation of discriminant analysis. Therefore, any one of the two highly correlated ratios was dropped from further analysis. Following nine ratios were deleted from the analysis having correlation higher than \pm 0.8 following Zhang, Altman, and Yen (2010).

Table 2: List if Ratios Deleted from Analysis

\begin{tabular}{|c|c|c|c|}
\hline Group & Ratio & Description & Source \\
\hline Profitability & EBIT/CL & EBIT / Current Liabilities & Gu (2002) \\
\hline Profitability & EBIT/S & EBIT / Sales & Ugurlu (2006) \\
\hline Profitability & NP/SE & Net Profit / Shareholder's Equity & Altman (1968) \\
\hline Profitability & EBIT/TA & $\begin{array}{c}\text { Earnings before Interest and Taxes / } \\
\text { Total Assets }\end{array}$ & Ugurlu (2006) \\
\hline Profitability & RE/TA & Retained Earnings / Total Assets & Altman (1968) \\
\hline Liquidity & QR & Quick Assets / Current Liabilities & Zmijewski (1984) \\
\hline Liquidity & CA/TA & Current Assets / Total Assets & Zmijewsky (1984) \\
\hline Leverage & SE/TA & Shareholder's Equity / Total Assets & Ugurlu (2006) \\
\hline Asset Efficiency & S/FA & Sales / Fixed Assets & $\begin{array}{c}\text { Eljelly \& Mansour } \\
\text { (2001) }\end{array}$ \\
\hline
\end{tabular}

After correlation analysis, remaining ratios (Table 3) were entered in the discriminant function using stepwise procedure in order to select best performing ratios. 


\section{Results and Discussion}

Discriminant function and logit analyses are used for the development of bankruptcy prediction model. These results are presented in this section along with discussion.

Table 3: List of Ratios Analyzed Along with Sources

\begin{tabular}{|c|c|c|}
\hline Ratio & Description & Source \\
\hline \multicolumn{3}{|c|}{ Profitability } \\
\hline $\mathrm{GP} / \mathrm{S}$ & Gross Profit / Sales & Ugurlu (2006) \\
\hline $\mathrm{NP} / \mathrm{S}$ & Net Profit / Sales (NP Margin) & Madalina et al. (2009) \\
\hline $\mathrm{EBIT} / \mathrm{TL}$ & $\begin{array}{c}\text { Earnings before Interest and Taxes / Total } \\
\text { Liabilities }\end{array}$ & Gu (2002) \\
\hline EPS & Earnings Per Share & Madalina et al. (2009) \\
\hline \multicolumn{3}{|c|}{ Liquidity } \\
\hline $\mathrm{CA} / \mathrm{CL}$ & Current Assets / Current Liabilities & $\mathrm{Gu}(2002)$ \\
\hline $\mathrm{CA} / \mathrm{TA}$ & Current Assets / Total Assets & Ugurlu (2006) \\
\hline $\mathrm{TL} / \mathrm{TA}$ & Total Liabilities / Total Assets & Ohlson (1980) \\
\hline $\mathrm{LTD} / \mathrm{TA}$ & Long-term Debt / Total Assets & Back (2001) \\
\hline \multicolumn{3}{|c|}{ Leverage } \\
\hline $\mathrm{FA} / \mathrm{SE}$ & Fixed Assets / Shareholder's Equity & Eljelly \& Mansour (2001) \\
\hline D/E Ratio & Total Debt / Shareholder's Equity & Zeitun, Tian, \& Keen (2007) \\
\hline SE/LTD & Shareholder's Equity / Long-term Debt & Ugurlu (2006) \\
\hline \multicolumn{3}{|c|}{ Assets Efficiency } \\
\hline NP/FA & Net Profit / Fixed Assets & Eljelly \& Mansour (2001) \\
\hline NP/TA & Net Profit/ Total Assets (ROA) & Ohlson (1980) \\
\hline $\mathrm{S} / \mathrm{CA}$ & Sales / Current Assets & Ugurlu (2006) \\
\hline $\mathrm{S} / \mathrm{TA}$ & Sales / Total Assets & Altman (1968) \\
\hline \multicolumn{3}{|c|}{ Growth } \\
\hline Sale G & Sales Growth (St - St-1) / St-1 & Madalina et al. (2009) \\
\hline NP G & Net Profit Growth (NPt - NPt-1) / NPt-1 & Madalina et al. (2009) \\
\hline TA G & Total Assets Growth (TAt - TAt-1) / TAt-1 & Madalina et al. (2009) \\
\hline \multicolumn{3}{|c|}{ Size } \\
\hline LnTA & $\log$ (Total Assets) & Ohlson (1980) \\
\hline LnTS & $\log$ (Total Sales) & Madalina et al. (2009) \\
\hline
\end{tabular}


Stepwise statistics table shows that four steps taken. In every step, one variable is included which add discriminating power in the function. Case-wise statistics in Table 4 also shows the tolerance level for the five included variables. These values showed that multi-collinearity is not a problem in this discriminant function. Guajarati (2004) stated that multi-collinearity is observed when tolerance value is below 0.10 for each independent variable.

Table 4: Stepwise Statistics of Discriminant Model

\begin{tabular}{|c|c|c|c|c|}
\hline \multicolumn{2}{|c|}{ Step } & Tolerance & Sig. of F to Remove & Wilks' Lambda \\
\hline \multirow{2}{*}{2} & Current Ratio & 1.000 & .000 & \\
\hline \multirow{2}{*}{3} & Current Ratio & .985 & .000 & .789 \\
\cline { 2 - 5 } & Earnings per Share & .985 & .000 & .744 \\
\cline { 2 - 5 } & Current Ratio & .971 & .000 & .677 \\
\cline { 2 - 5 } & Earnings per Share & .984 & .000 & .666 \\
\hline \multirow{2}{*}{4} & Log (Total Sales) & .985 & .005 & .590 \\
\cline { 2 - 5 } & Current Ratio & .969 & .000 & .630 \\
\cline { 2 - 5 } & Earnings per Share & .981 & .000 & .617 \\
\cline { 2 - 5 } & Log (Total Sales) & .966 & .003 & .568 \\
\cline { 2 - 5 } & Net Profit to Sales & .978 & .029 & .543 \\
\hline
\end{tabular}

\subsection{Selection of best predictor variables for discriminant function}

After step wise entry of predictors, four variables are selected and are highly significant in discriminating between two groups with $\mathrm{p}$ value less than 0.000 .

Table 5: Variables Entered / Removed a, b, c, d

\begin{tabular}{|c|c|c|c|c|}
\hline \multirow{2}{*}{ Step } & \multirow{2}{*}{ Variables Entered } & \multirow{2}{*}{ Lambda } & \multicolumn{2}{|c|}{ Exact F } \\
\cline { 3 - 5 } & & & Statistic & Sig. \\
\hline 1 & Current Ratio & .744 & 33.647 & .000 \\
\hline 2 & Earnings per Share & .590 & 33.740 & .000 \\
\hline 3 & Log (Total Sales) & .543 & 26.881 & .000 \\
\hline 4 & Net Profit to Sales & .517 & 22.212 & .000 \\
\hline
\end{tabular}

At each step, the variable that minimizes the overall Wilks' Lambda is entered.

a. Maximum number of steps is 40 .

b. Maximum significance of $\mathrm{F}$ to enter is .05 . 
Table 6: Standardized Canonical Discriminant Function Coefficients

\begin{tabular}{|c|c|}
\hline \multirow{2}{*}{ Ratios } & Function 1 \\
\cline { 2 - 2 } & Coefficients \\
\hline Current Ratio & .620 \\
\hline Earnings per Share & .587 \\
\hline Log (Total Sales) & .441 \\
\hline Net Profit to Sales & .323 \\
\hline
\end{tabular}

The weights of the Z-Score model are almost similar to the regression analysis. Coefficients given in Table 6 represent the importance of predictor variables for the calculation of Z-Score model. It is evident that all four variables affect the Z-Score positively.

Table 7: Functions at Group Centroids

\begin{tabular}{|c|c|}
\hline & Z-Score \\
\hline Bankrupt & -0.957 \\
\hline Non-Bankrupt & 0.957 \\
\hline
\end{tabular}

Table 7 shows that the group means or the centroid for the bankrupt companies is -0.957 and for non-bankrupt companies is 0.957 . Cases are considered bankrupt or non-bankrupt if the Z-Score of the company is near to -0.957 or 0.957 respectively. By using symmetry rule, cutoff point is calculated on the basis of means of the centroids of the two groups. e.g., mean of $\mathrm{Z}_{\mathrm{g} 1}$ and $\mathrm{Z}_{\mathrm{g} 2}$.

$$
M=\left(Z_{g 1}+Z_{g 2}\right) / 2=-0.957+0.957=0
$$

Cutoff point for this new developed model is 0 and model is:-

$$
\text { Z-Score }=0.620 X_{1}+0.587 X_{2}+0.441 X_{3}+0.323 X_{4}
$$

Where,

$X_{1}=$ Current Ratio, $X_{2}=$ Earnings per Share, $X_{3}=$ Log (Total Sales), $X_{4}=$ Net Profit to Sales

\subsection{Goodness of fit statistics for new model}

Overall Wilks' lambda indicates the significance of the discriminant function. It tests the hypothesis that the mean of predictor financial ratios is equal across the bankrupt and non-bankrupt groups. Chi-square statistic for this Wilks' lambda is 
Table 8: Wilks' Lambda

\begin{tabular}{|c|c|c|c|}
\hline Test of Function(s) & Wilks' Lambda & Chi-square & Sig. \\
\hline 1 & 0.517 & 63.383 & .000 \\
\hline
\end{tabular}

Table 9: Eigenvalues

\begin{tabular}{|c|c|c|c|c|}
\hline Function & Eigenvalue & $\%$ of Variance & Cumulative \% & Canonical Correlation \\
\hline 1 & $.935 \mathrm{a}$ & 100.0 & 100.0 & .70 \\
\hline
\end{tabular}

a. First 1 canonical discriminant functions were used in the analysis.

statistically significant at $\mathrm{p}$ value $<.01$. Therefore, it can be concluded that there exists a significant relationship between independent predictors and the dependent groups. Canonical correlation of 0.70 represents the greater strength of relationship between selected variables and bankruptcy status.

\subsection{Company wise prediction results}

Table 10 presents the company wise actual membership along with forecasted membership in their respective groups based on developed Z-Score from model. Probability for the bankrupt and non-bankrupt companies to join bankrupt or non-bankrupt group respectively is also shown. Z-Score for all companies is calculated along with Squared Mahalanobis distance to centroid. This distance is used for the identification of outlier case.

Table 10: Casewise Statistics

\begin{tabular}{|c|c|c|c|c|c|c|}
\hline \multirow{2}{*}{$\begin{array}{c}\text { Case Num- } \\
\text { ber }\end{array}$} & \multirow{2}{*}{$\begin{array}{l}\text { Actual } \\
\text { Group }\end{array}$} & \multirow{2}{*}{$\begin{array}{l}\text { Predicted } \\
\text { Group }\end{array}$} & \multicolumn{2}{|c|}{ Probability of Joining } & \multirow{2}{*}{$\begin{array}{l}\text { Sq. Mahalanobis } \\
\text { Distance to Cen- } \\
\text { troid }\end{array}$} & \multirow{2}{*}{$\begin{array}{c}\text { Discrim- } \\
\text { inant } \\
\text { Scores }\end{array}$} \\
\hline & & & group I & group II & & \\
\hline 1 & 0 & 0 & .991 & .009 & 2.270 & 2.464 \\
\hline 2 & 0 & 0 & .541 & .459 & .761 & .085 \\
\hline 3 & 0 & 0 & .691 & .309 & .288 & .420 \\
\hline 4 & 0 & 0 & .741 & .259 & .168 & .548 \\
\hline 5 & 0 & 0 & .857 & .143 & .000 & .937 \\
\hline 6 & 0 & $1^{* *}$ & .960 & .040 & .489 & -1.657 \\
\hline 7 & 0 & 0 & .608 & .392 & .531 & .228 \\
\hline 8 & 0 & 0 & .800 & .200 & .054 & .724 \\
\hline
\end{tabular}




\begin{tabular}{|c|c|c|c|c|c|c|}
\hline 9 & 0 & 0 & .826 & .174 & .021 & .814 \\
\hline 10 & 0 & 0 & .768 & .232 & .110 & .625 \\
\hline 11 & 0 & 0 & .737 & .263 & .176 & .538 \\
\hline 12 & 0 & 0 & .798 & .202 & .058 & .717 \\
\hline 13 & 0 & 0 & .999 & .001 & 6.095 & 3.426 \\
\hline 14 & 0 & 0 & .832 & .168 & .015 & .834 \\
\hline 15 & 0 & 0 & .712 & .288 & .236 & .472 \\
\hline 16 & 0 & 0 & .717 & .283 & .224 & .485 \\
\hline 17 & 0 & 0 & .998 & .002 & 4.786 & 3.145 \\
\hline 18 & 0 & 0 & .747 & .253 & .154 & .564 \\
\hline 19 & 0 & 0 & .967 & .033 & .644 & 1.760 \\
\hline 20 & 0 & 0 & .534 & .466 & .787 & .070 \\
\hline 21 & 0 & 0 & .668 & .332 & .352 & .364 \\
\hline 22 & 0 & $1^{* *}$ & .956 & .044 & .430 & -1.613 \\
\hline 23 & 0 & 0 & .991 & .009 & 2.165 & 2.429 \\
\hline 24 & 0 & 0 & .999 & .001 & 6.726 & 3.551 \\
\hline 25 & 0 & 0 & .567 & .433 & .665 & .142 \\
\hline 26 & 0 & 0 & .744 & .256 & .161 & .556 \\
\hline 27 & 0 & 0 & .998 & .002 & 5.705 & 3.346 \\
\hline 28 & 0 & 0 & .542 & .458 & .755 & .089 \\
\hline 29 & 0 & 0 & .518 & .482 & .846 & .038 \\
\hline 30 & 0 & 0 & .814 & .186 & .035 & .771 \\
\hline 31 & 0 & 0 & .947 & .053 & .305 & 1.510 \\
\hline 32 & 0 & 0 & .954 & .046 & .390 & 1.582 \\
\hline 33 & 0 & 0 & .669 & .331 & .348 & .367 \\
\hline 34 & 0 & 0 & .701 & .299 & .263 & .445 \\
\hline 35 & 0 & 0 & .978 & .022 & 1.035 & 1.975 \\
\hline 36 & 0 & 0 & .823 & .177 & .024 & .804 \\
\hline 37 & 0 & 0 & .892 & .108 & .022 & 1.104 \\
\hline 38 & 0 & 0 & .632 & .368 & .457 & .281 \\
\hline 39 & 0 & 0 & .690 & .310 & .291 & .418 \\
\hline 40 & 0 & 0 & .573 & .427 & .646 & .154 \\
\hline 41 & 0 & 0 & .533 & .467 & .787 & .070 \\
\hline 42 & 0 & 0 & .719 & .281 & .217 & .491 \\
\hline
\end{tabular}




\begin{tabular}{|c|c|c|c|c|c|c|}
\hline 43 & 0 & 0 & .999 & .001 & 7.745 & 3.740 \\
\hline 44 & 0 & 0 & .930 & .070 & .153 & 1.349 \\
\hline 45 & 0 & 0 & .754 & .246 & .138 & .586 \\
\hline 46 & 0 & 0 & .797 & .203 & .059 & .714 \\
\hline 47 & 0 & 0 & 1.000 & .000 & 11.059 & 4.283 \\
\hline 48 & 0 & 0 & .541 & .459 & .758 & .087 \\
\hline 49 & 0 & 0 & .740 & .260 & .169 & .546 \\
\hline 50 & 0 & 0 & .719 & .281 & .219 & .490 \\
\hline 51 & 1 & 1 & .947 & .053 & .303 & -1.508 \\
\hline 52 & 1 & 1 & .544 & .456 & .749 & .092 \\
\hline 53 & 1 & 1 & .602 & .398 & .550 & -.216 \\
\hline 54 & 1 & 1 & .645 & .355 & .418 & -.311 \\
\hline 55 & 1 & 1 & .963 & .037 & .555 & -1.702 \\
\hline 56 & 1 & 1 & .922 & .078 & .110 & -1.288 \\
\hline 57 & 1 & 1 & .862 & .138 & .000 & -.959 \\
\hline 58 & 1 & 1 & .960 & .040 & .503 & -1.666 \\
\hline 59 & 1 & 1 & .838 & .162 & .010 & .859 \\
\hline 60 & 1 & 1 & .820 & .180 & .027 & -.792 \\
\hline 61 & 1 & 1 & .527 & .473 & .813 &. .055 \\
\hline 62 & 1 & 1 & .612 & .388 & .517 & .238 \\
\hline 63 & 1 & 1 & .960 & .040 & .484 & -1.653 \\
\hline 64 & 1 & 1 & .971 & .029 & .773 & -1.837 \\
\hline 65 & 1 & 1 & .963 & .037 & .546 & -1.696 \\
\hline 66 & 1 & 1 & .792 & .208 & .066 & -.700 \\
\hline 67 & 1 & 1 & .954 & .046 & .398 & -1.588 \\
\hline 68 & 1 & 1 & .998 & .002 & 5.152 & -3.227 \\
\hline 69 & 1 & 1 & .658 & .342 & .379 & -.342 \\
\hline 70 & 1 & 1 & .911 & .089 & .065 & -1.212 \\
\hline 71 & 1 & 1 & .819 & .181 & .029 & -.788 \\
\hline 72 & 1 & 1 & .708 & .292 & .244 & -.463 \\
\hline 73 & 1 & 1 & .705 & .295 & .252 & -.455 \\
\hline 74 & 1 & 1 & .922 & .078 & .110 & -1.290 \\
\hline 75 & 1 & 1 & .820 & .180 & .027 &. .793 \\
\hline 76 & 1 & 1 & .968 & .032 & .678 & -1.781 \\
\hline
\end{tabular}




\begin{tabular}{|c|c|c|c|c|c|c|}
\hline 77 & 1 & 1 & .938 & .062 & .209 & -1.415 \\
\hline 78 & 1 & 1 & .521 & .479 & .836 & -.043 \\
\hline 79 & 1 & 1 & .556 & .444 & .705 & -.118 \\
\hline 80 & 1 & 1 & .963 & .037 & .556 & -1.703 \\
\hline 81 & 1 & 1 & .653 & .347 & .394 & -.330 \\
\hline 82 & 1 & 1 & .726 & .274 & .200 & -.510 \\
\hline 83 & 1 & 1 & .963 & .037 & .551 & -1.700 \\
\hline 84 & 1 & 1 & .563 & .437 & .681 & -.132 \\
\hline 85 & 1 & 1 & .984 & .016 & 1.425 & -2.151 \\
\hline 86 & 1 & 1 & .920 & .080 & .100 & -1.273 \\
\hline 87 & 1 & 1 & .543 & .457 & .751 & -.091 \\
\hline 88 & 1 & 1 & .715 & .285 & .227 & -.481 \\
\hline 89 & 1 & 1 & .836 & .164 & .011 & -.851 \\
\hline 90 & 1 & 1 & .668 & .332 & .351 & -.365 \\
\hline 91 & 1 & 1 & .544 & .456 & .748 & .092 \\
\hline 92 & 1 & 1 & .869 & .131 & .001 & -.988 \\
\hline 93 & 1 & 1 & .558 & .442 & .698 &. .122 \\
\hline 94 & 1 & 1 & .797 & .203 & .059 &. .715 \\
\hline 95 & 1 & 1 & .744 & .256 & .161 &. .556 \\
\hline 96 & 1 & 1 & .860 & .140 & .000 & .947 \\
\hline 97 & 1 & 1 & .857 & .143 & .000 & -.935 \\
\hline 98 & 1 & 1 & .988 & .012 & 1.858 & -2.320 \\
\hline 99 & 1 & 1 & .955 & .045 & .405 & -1.593 \\
\hline 100 & 1 & 1 & 0.854 & 0.146 & 0.001 & -0.924 \\
\hline
\end{tabular}

According to SPSS user guide ${ }^{5}$, squared mahalanobis distance to centroid is used to detect the outliers from the sample. It is the measure of distance of each case values on independent predictor from the mean of all cases. Critical value for chi-square at 0.01 significance level and $5 \mathrm{~d}$. F. was calculated in by writing the IDF.CHISQ $(.95,5)$ command. It returned with the critical value of 11.07. Entire column of Mahalanobis $\mathrm{D}^{2}$ was scanned for the values greater than 11.07. The greatest squared distance was found 11.05. Therefore, none of the case is outlier in data set. Table 10 also shows that case number 6 and 22 are miss-classified.

5 IBM SPSS Statistics 20 Core System User's Guide, SPSS Inc. 


\subsection{Classification accuracy results}

Table 11 summarizes classification result of new Z-Score model.

Over all accuracy of the developed model is $98 \%$. While $100 \%$ t of the bankrupt companies and $96 \%$ non-bankrupt companies were correctly classified.

In logit analysis, data of one hundred companies consisting of fifty bankrupt and fifty non-bankrupt companies was used. Out of twenty-nine ratios, fourteen ratios

Table 11: Classification Resultsa

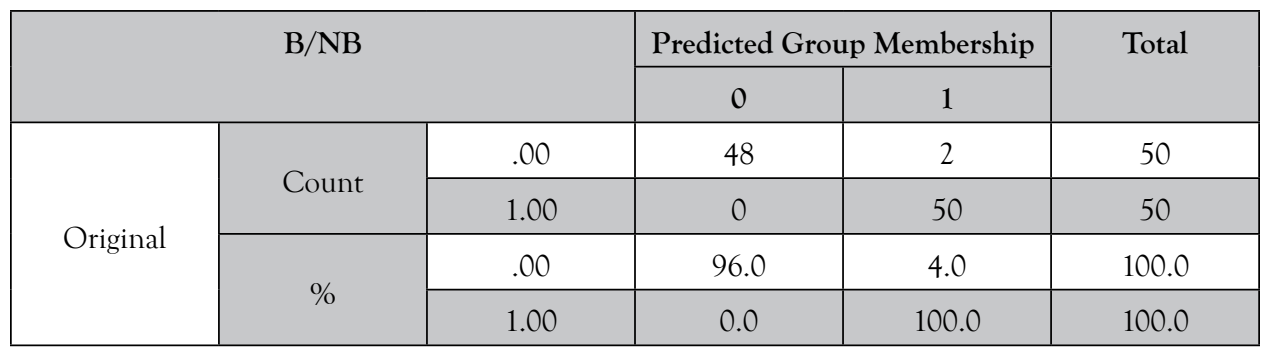

a. $98.0 \%$ of original grouped cases correctly classified.

Table 12: Coefficients Table of Logit Model

\begin{tabular}{|c|c|c|c|c|}
\hline Variables & Coefficient & Std. Error & z-Statistic & Prob. \\
\hline C & 13.38 & 5.47 & 2.45 & 0.01 \\
\hline GPS & -6.43 & 3.45 & -1.86 & 0.06 \\
\hline CACL & -5.03 & 1.39 & -3.62 & 0.00 \\
\hline LNTS & -0.44 & 0.25 & -1.76 & 0.08 \\
\hline Obs with Dep=0 & 50 & Total Obs & 100 & \\
\hline Obs with Dep=1 & 50 & & & \\
\hline
\end{tabular}

GPS $=$ gross profit to total sales ratio, $\mathrm{CACL}=$ current assets to current liabilities, $\mathrm{LNTS}=\ln$ (total assets)

Dependent Variable: BNB

Method: ML - Binary Logit (Quadratic hill climbing)

passed the mean dissimilarity test among two groups of bankrupt and non-bankrupt enterprises and these fourteen ratios were used in the analysis. Initially, ratio with the most significant p-value was entered. Subsequently, following a forward looking procedure, other variables were entered and dropped, if found insignificant (e.g., p value $>$.05). Finally, the three significant variables selected in the final model. On the 
basis of these variables, bankruptcy prediction model was formulated.

$$
\text { Logit Score }=\frac{1}{1+\mathrm{e}^{-(13.38-6.43 \text { GPS }-5.03 \text { CACL- } 0.44 \text { LNTA })}}
$$

Z-statistics of the coefficients for statistical significance reported in logit as it uses ML estimation, which is usually a large sample method. The standard error formulae used in the ML estimation are valid asymptotically only.

\subsection{Interpretation of the coefficient estimates}

As Logit estimation is non-linear estimation, its coefficient interpretation is little bit different. Brooks (2008) stated that mean values for each explanatory variable in Logit model shall be calculated for the correct interpretation of coefficients. Therefore, mean values for the explanatory variables for Logit analysis are -0.193, 1.106 and 20.326 respectively. Now the logistic function is calculated.

$$
\mathrm{P}^{\wedge}{ }_{\mathrm{i}}=\frac{1}{1+\mathrm{e}^{-\left(13.38-6.43^{*}-0.193-5.03^{*} 1.106-0.44^{*} 20.326\right)}}=\frac{1}{1+\mathrm{e}^{-(.114)}}=0.53
$$

So, with one-unit increase in GP to S, probability of the case to join group 1, e.g. $\mathrm{Yi}=1$, will decrease by $(-6.43 \times 0.53)=3.40$. One-unit increase in CA to CL will cause a decrease in the probability that the outcome corresponding to $\mathrm{y}_{\mathrm{i}}=1$ will occur by $(-5.03 \times 0.53)=2.66$. The corresponding changes in probability for variable LN to TS are $(-0.44 \times 0.53)=0.23$. These are also called marginal effects andare calculated in a spreadsheet as suggested by Brooks (2008).

\subsection{Classification accuracy of the estimated model}

As previously mentioned, it is usual to use a cutoff point of 0.5 for classification of an enterprise as bankrupt and non-bankrupt.

Table 13 shows case wise accuracy of the sampled companies using 0.5 as cutoff point. Fifty non-bankrupt and fifty bankrupt companies were analyzed. Logit score correctly classifies 94 companies in which 48 are non-bankrupt and 46 are bankrupt. Case number six and twenty-two were miss-classified in non-bankrupt group and case number fifty-nine, seventy-eight, ninety-one and ninety-eight were miss-classified from bankrupt group. With reference of table 1 it can be identified that Nazir Cotton Mills Ltd. and Accord Textiles Ltd. from non-bankrupt group and Mehran Sugar Mills Ltd., Fazal Textile Mills Ltd., Bela Automotives Ltd. and Safa Textiles Ltd. from bankrupt groups are miss-classified firms when prediction is made through logit model. 
Table 4.13: Case wise Classification of Sampled Companies

\begin{tabular}{|c|c|c|c|c|c|c|}
\hline \multicolumn{4}{|c|}{ Non-Bankrupt Group } & \multicolumn{3}{|c|}{ Bankrupt Group } \\
\hline Sr. & Actual & Fitted & Residual & Actual & Fitted & Residual \\
\hline 1 & 0 & 0.07 & -0.07 & 1 & 0.97 & 0.03 \\
\hline 2 & 0 & 0.27 & -0.27 & 1 & 0.81 & 0.19 \\
\hline 3 & 0 & 0.02 & -0.02 & 1 & 0.65 & 0.35 \\
\hline 4 & 0 & 0.01 & -0.01 & 1 & 0.88 & 0.12 \\
\hline 5 & 0 & 0.09 & -0.09 & 1 & 1.00 & 0.00 \\
\hline 6 & 0 & $0.99^{* *}$ & -0.99 & 1 & 0.83 & 0.17 \\
\hline 7 & 0 & 0.08 & -0.08 & 1 & 0.87 & 0.13 \\
\hline 8 & 0 & 0.23 & -0.23 & 1 & 1.00 & 0.00 \\
\hline 9 & 0 & 0.13 & -0.13 & 1 & $0.45^{* *}$ & 0.55 \\
\hline 10 & 0 & 0.04 & -0.04 & 1 & 0.95 & 0.05 \\
\hline 11 & 0 & 0.00 & 0.00 & 1 & 0.74 & 0.26 \\
\hline 12 & 0 & 0.06 & -0.06 & 1 & 0.75 & 0.25 \\
\hline 13 & 0 & 0.00 & 0.00 & 1 & 0.99 & 0.01 \\
\hline 14 & 0 & 0.00 & 0.00 & 1 & 1.00 & 0.00 \\
\hline 15 & 0 & 0.10 & -0.10 & 1 & 1.00 & 0.00 \\
\hline 16 & 0 & 0.01 & -0.01 & 1 & 0.99 & 0.01 \\
\hline 17 & 0 & 0.00 & 0.00 & 1 & 0.98 & 0.02 \\
\hline 18 & 0 & 0.00 & 0.00 & 1 & 1.00 & 0.00 \\
\hline 19 & 0 & 0.00 & 0.00 & 1 & 0.71 & 0.29 \\
\hline 20 & 0 & 0.12 & -0.12 & 1 & 0.67 & 0.33 \\
\hline 21 & 0 & 0.07 & -0.07 & 1 & 0.96 & 0.04 \\
\hline 22 & 0 & $0.99^{* *}$ & -0.99 & 1 & 0.99 & 0.01 \\
\hline 23 & 0 & 0.01 & -0.01 & 1 & 0.97 & 0.03 \\
\hline 24 & 0 & 0.00 & 0.00 & 1 & 0.99 & 0.01 \\
\hline 25 & 0 & 0.33 & -0.33 & 1 & 0.99 & 0.01 \\
\hline 26 & 0 & 0.02 & -0.02 & 1 & 0.99 & 0.01 \\
\hline 27 & 0 & 0.32 & -0.32 & 1 & 0.90 & 0.10 \\
\hline 28 & 0 & 0.17 & -0.17 & 1 & $0.27^{* *}$ & 0.73 \\
\hline 29 & 0 & 0.37 & -0.37 & 1 & 0.98 & 0.02 \\
\hline 30 & 0 & 0.10 & -0.10 & 1 & 0.99 & 0.01 \\
\hline 31 & 0 & 0.01 & -0.01 & 1 & 0.91 & 0.09 \\
\hline
\end{tabular}




\begin{tabular}{|c|c|c|c|c|c|c|}
\hline 32 & 0 & 0.00 & 0.00 & 1 & 0.98 & 0.02 \\
\hline 33 & 0 & 0.06 & -0.06 & 1 & 1.00 & 0.00 \\
\hline 34 & 0 & 0.07 & -0.07 & 1 & 0.81 & 0.19 \\
\hline 35 & 0 & 0.00 & 0.00 & 1 & 1.00 & 0.00 \\
\hline 36 & 0 & 0.00 & 0.00 & 1 & 1.00 & 0.00 \\
\hline 37 & 0 & 0.00 & 0.00 & 1 & 0.80 & 0.20 \\
\hline 38 & 0 & 0.03 & -0.03 & 1 & 0.99 & 0.01 \\
\hline 39 & 0 & 0.03 & -0.03 & 1 & 1.00 & 0.00 \\
\hline 40 & 0 & 0.15 & -0.15 & 1 & 0.95 & 0.05 \\
\hline 41 & 0 & 0.09 & -0.09 & 1 & $0.49^{* *}$ & 0.51 \\
\hline 42 & 0 & 0.02 & -0.02 & 1 & 1.00 & 0.00 \\
\hline 43 & 0 & 0.00 & 0.00 & 1 & $0.47^{* *}$ & 0.53 \\
\hline 44 & 0 & 0.00 & 0.00 & 1 & 1.00 & 0.00 \\
\hline 45 & 0 & 0.01 & -0.01 & 1 & 0.98 & 0.02 \\
\hline 46 & 0 & 0.11 & -0.11 & 1 & 0.84 & 0.16 \\
\hline 47 & 0 & 0.05 & -0.05 & 1 & 1.00 & 0.00 \\
\hline 48 & 0 & 0.22 & -0.22 & 1 & 1.00 & 0.00 \\
\hline 49 & 0 & 0.05 & -0.05 & 1 & 0.97 & 0.03 \\
\hline 50 & 0 & 0.03 & -0.03 & 1 & 1.00 & 0.00 \\
\hline
\end{tabular}

${ }^{* *}$ misclassified cases

Table 4.14: Predictive Classification Accuracy, Sensitivity and Specificity

\begin{tabular}{|c|c|c|c|c|c|c|}
\hline & \multicolumn{3}{|c|}{ Estimated Equation } & \multicolumn{3}{c|}{ Constant Probability } \\
\cline { 2 - 7 } & Dep $=0$ & Dep $=1$ & Total & Dep $=0$ & Dep $=1$ & Total \\
\hline $\mathrm{P}($ Dep $=1)<=\mathrm{C}$ & 48 & 4 & 52 & 50 & 50 & 100 \\
\hline $\mathrm{P}($ Dep=1)>C & 2 & 46 & 48 & 0 & 0 & 0 \\
\hline Total & 50 & 50 & 100 & 50 & 50 & 100 \\
\hline Correct & 48 & 46 & 94 & 50 & 0 & 50 \\
\hline$\%$ Correct & 96 & 92 & 94 & 100 & 0 & 50 \\
\hline$\%$ Incorrect & 4 & 8 & 6 & 0 & 100 & 50 \\
\hline
\end{tabular}


Table 4.14 shows that one hundred companies use are instead of were analyzed in which fifty were in each of non-bankrupt and bankrupt group. Out of 100 cases, 48 companies were having a score greater than cutoff point of 0.5 and 52 companies were having a score less than or equal to the cutoff point. Whole sample was $94 \%$ correctly classified with a specificity of $96 \%$ and sensitivity of $92 \%$. Sensitivity is the percentage of the positive cases of group 1 to join group 1 whereas specificity is the percentage of the positive response of group 0 to join group 0 .

Figure 1 shows the actual observation i.e., non-bankrupt or bankrupt with the thick horizontal line. Fitted values are shown in up and down line and residuals are shown with the gray bars. Initial fifty observations i.e., non-bankrupt companies are shown with zero on left axis and remaining fifty companies' observations are shown with one on the left side.

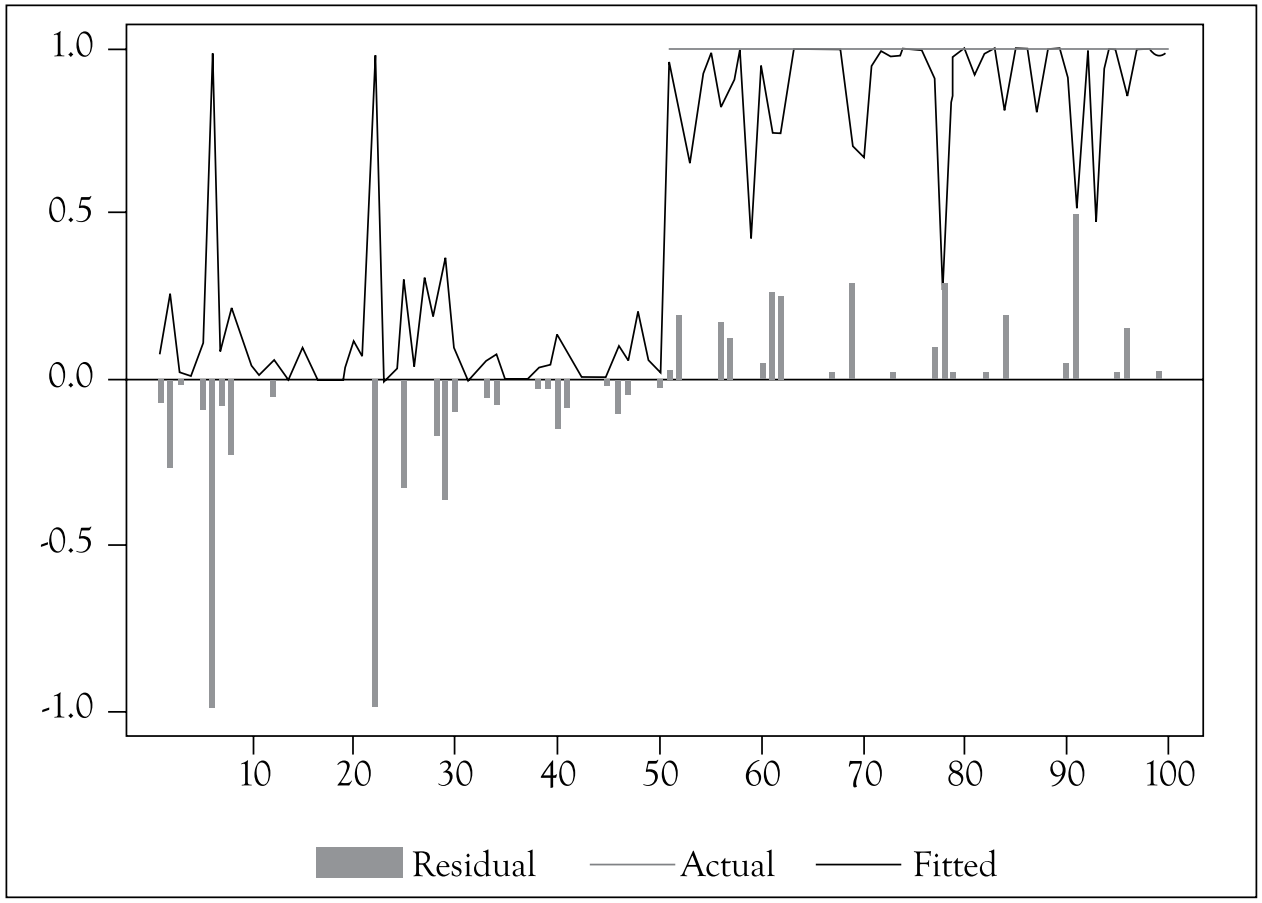

Figure 1: Actual Fitted Residual Graph

\subsection{Goodness of fit statistics for new developed model}

Brooks (2008) recommends count $\mathrm{R}^{2}$, Pseudo $\mathrm{R}^{2}$ and LR-stat as goodness of fit measures for the limited dependent variable models. Gujarati (2004) stated the count $\mathrm{R}^{2}$ is the measure of the model fit in the Logit models. It is same as the classification 
accuracy previously mentioned. It is the ratio of correct predictions to total observations. Out of 100 cases, 94 are correctly classified i.e., Count $\mathrm{R}^{2}=94 \%$ which suffices the model fit criteria.

Another measure of model fit known as Pseudo $\mathrm{R}^{2}$ is used rather $\mathrm{R}^{2}$ or adjusted $\mathrm{R}^{2}$ but it is interpreted in the usual fashion. It compares the likelihood of the full model with the empty model.

$$
\text { Pseudo }-R^{2}=1-\frac{L L F}{L L F_{0}}
$$

Where $L L F_{0}$ is the log likelihood of the restricted model where all of the coefficient are zero and LLF is the maximum value of the log likelihood function for logit model is also known as McFadden $\mathrm{R}^{2}$. Its value is $70 \%$ which represent a good model fit. Alike linear regression, changes in the likelihood ratio is used to test the explanatory power of the new model. It tests the hypothesis that $\square_{1}=\square_{2}=\square_{3}=\square_{4}=\square_{5}=$ 0 and it is equivalent to $\mathrm{F}$ test in the linear regression. LR statistics follows a Chisquared distribution with the degree of freedom equal to the number of explanatory variables. It is 96.15 and is highly significant at $p$ value $<0.000$ which shows the joint significance of the three explanatory variables. Hosmer Lemeshow test also confirmed the validity of the model with H-L Statistic 0.7555 at $\mathrm{P}$ value $>0.05$ confirming the inability to reject null hypothesis.

Hence, these two models are developed with high accuracy. Various bankruptcy prediction models which were originally developed by the home countries using the data of the companies of the specific region of the world may not be applied to corporate sector of Pakistan due to historical background and differences in accounting

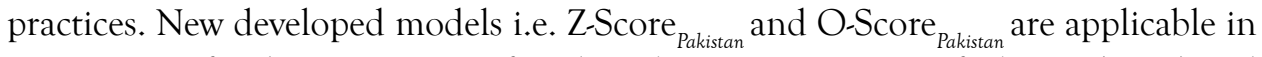
various ways for the assessment of credit risk on same process of Altman (1968) and Ohlson (1980) but specifically in Pakistani context.

\section{Conclusion}

This study develops a multivariate discriminant function and a probability model for the credit evaluation of Pakistani companies. Four ratios namely current ratio, earnings per share, log of total sales and net profit to sales were selected by the discriminant function out of six categories, which discriminates among the bankrupt or financially distressed and non-distressed enterprises. Accuracy of the model is excellent as it correctly classifies all fifty bankrupt companies. On the other hand, forty-eight out of fifty non-bankrupt companies were correctly classified in the non-bankrupt group. While, two non-bankrupt companies were misclassified in the bankrupt group. Percentage of correct predictions of the Z-Score model represents the accuracy of the model and it is same as $\mathrm{R}^{2}$ of multiple regressions. Over all accuracy of the developed 
model is 98 percent. While, 100\% of the bankrupt companies and $96 \%$ percent of non-bankrupt companies are correctly classified by the function. The results of the study are generalizable to all non-financial firms because sample includes bankrupt and non-bankrupt companies form several sectors.

Fourteen variables which passed the mean difference test are entered in the logit model using forward looking approach. Eventually, final model was formulated with three significant financial ratios. On the basis of cutoff point, new model was evaluated for prediction accuracy. It correctly classifies $96 \%$ non-bankrupt companies and 92\% bankrupt companies. Overall accuracy was $94 \%$ for this model.

\subsection{Recommendations and practical implications}

Results of the study showed that both models produce good prediction results with greater accuracy. The models developed in this study are capable of fruitful application to identify potential problems which take the enterprises into bankruptcy. Use of these models will prevent corporate sector form financial problems.

It is very crucial that analysts and researchers carefully understand the prediction models during their application, rehabilitative actions, and decision making. New developed models are based on Pakistani data and are better able to predict bankruptcy than those which were developed with other countries data set.

Based on the collected historical data, this four factor model can be used to calculate the estimated PD. In this regard, these models might be used for guidance to divided loan applicants into different categories in order to make their classification with the purpose of making the bank enable to focus on distressed or unhealthy companies for their close monitoring. So, they can be a useful tool to assist the internal control of companies.

Moreover, corporate account receivable managers, employees and customers will also get benefit from the new developed models. Employees can use these models to analyze the health of the company to assess their job security and stability in the company. Customers of the company are able to assess that company to meet its future promises.

\subsection{Suggestions for future research}

This study opens following directions for future research. New models for bankruptcy prediction are developed in this study and tested for within the sample accuracy of these models. A further research can be conducted to test these models for out of the sample companies. Potential performance of the models can also be enhanced 
with the inclusion of macroeconomic variables regarding the money market activities, economic growth, and socio-economic conditions to forecast bankruptcy before actual bankruptcy. Other techniques which have been used in many countries of the world for bankruptcy prediction i.e., hazard model, CHID decision trees, neural networks and two stage forecast can also be applied to develop bankruptcy prediction models in Pakistan's context.

\section{References}

Abdullah, N. A. H., Halim, A., Ahmad, H., \& Rus, R. (2008). Predicting corporate failure of Malaysia's listed companies: Comparing multiple discriminant analysis, logistic regression and the hazard Model. International Research Journal of Finance and Economics, 15, 201-217.

Agarwala, V., \& Taffler, R. (2008). Comparing the performance of market-based and accounting-based bankruptcy prediction models. Journal of Banking $\mathscr{E}$ Finance, 32(8), 1541-1551.

Altman, E. I., \& Hotchkiss, E. (2006). Corporate Financial Distress and Bankruptcy (3 ${ }^{\text {rd }}$ ed.). John Wiley $\&$ Sons, Inc.

Altman, E. I., \& Saunders, A. (1998). Credit risk measurement: developments over the last 20 years. Journal of Banking and Finance, 21(11-12), 1721-42.

Altman, E. I. (1983). Corporate financial distress: A complete guide to predicting, avoiding, and dealing with bankruptcy. New York: John Wiley \& Sons.

Altman, E. I. (1968). Financial ratio, discriminant analysis and prediction of corporate bankruptcy. Journal of Finance, 23(4), 589-610.

Aziz, M. A., \& Dar, H. A. (2006). Predicting corporate bankruptcy: Where we stand? Corporate Governance, 6(1), 18-33.

Back, P. (2001). Testing liquidity measures as bankruptcy prediction variables. The Finnish Journal of Business Economics, 7(3), 309-327.

Beaver, W. (1966). Financial ratios as predictors of failure. Journal of Accounting Research, 4, 71-111.

Brooks, C. (2008). Introductory Econometrics for Finance (2 ${ }^{\text {nd }}$ ed.). Cambridge University Press.

Chye, K. H., Hye, L. M., Meng, L. A., \& Meng, T. T. (1989). What do your financial statements tell about your company's and performance? Singapore: NTI-Peat Marwick, Entrepreneurship Development Centre.

Coats, P., \& Fant, L. (1993). Recognizing financial distress patterns using a neural network tool. Financial Management, 3(22), 142-155.

Dambolena, I. G., \& Khoury, S. G. (1980). Ratio stability and corporate failure. Journal of Finance, 35(9), 1107-1126.

Deakin, E. B. (1972). A discriminant analysis of predictors of business failure. Journal of Accounting 
Research, 10(3), 167-179.

Edmister, R. O. (1972). An empirical test of financial ratio analysis for small business failure prediction. Journal of Finance and Quantitative Analysis, 7(2), 1477-1493.

Eidleman, J. G. (1995). Z-scores: A guide to failure prediction. The CPA Journal, 65(1), 52-54.

Eljelly, M. A., \& Mansour, I. H. F. (2001). Predicting private companies' failure in the Sudan. Journal of African Business, 2(2), 23-43.

Gentry, J. A., Newbold, P. \& Whitford, D. T. (1985). Classifying bankrupt firms with funds flow components. Journal of Accounting Research, 23(1), 146-160.

Gu, Z. (2002). Analyzing bankruptcy in the restaurant industry: A multiple discriminant model. Hospitality Management, 21(1), 25-42.

Gujarati, D. N. (2004). Basic Econometrics (4 $4^{\text {th }}$ ed.). McGraw-Hill, New York.

Harlan, D. P., \& Marjorie, B. P. (2002). Predicting corporate financial distress: Reflections on choice based sample bias. Journal of Economic and Finance, 26(2), 184.

Hasanain, A., \& Shah, S. A. A. (2012). Investigating the proposed changes to Pakistan's corporate bankruptcy code. CREB, LSE. Working Paper No. 01-12.

Jones, F. L. (1987). Current techniques in bankruptcy prediction. Journal of Accounting Literature, 6(1), $131-164$.

Kidane, H. W. (2004). Predicting financial distress in IT and services companies in South Africa. M.Com Dissertation, University of the Free State, Bolemfontein.

Libby, R. (1975). Accounting ratios and the prediction of failure: Some behavioral evidence. Journal of Accounting Research, 13(1), 150-161.

Madalina, E. A., Mugurel, L. A., \& Marin, A. (2009). Using financial ratios to identify Romanian distressed companies. Economia. Seria Management, 12(1), 46-55.

Muller, G. H., Bruwer, B. W., \& Hamman, W. D. (2009). Predicting financial distress of companies listed on the JSE: A comparison of techniques. South African Journal of Business Management, 40(1), 21-32.

Newton, G. (2009). Bankruptcy and insolvency accounting: Practice and procedure ( $7^{\text {th }}$ ed.) John Wiley \& Sons.

Ohlson, J. (1980). Financial ratios and probabilistic prediction of bankruptcy. Journal of Accounting Research, 18(1), 109-131.

Securities and Exchange Commission of Pakistan. (2009). Background of the committee to review Corporate Rehabilitation Act. Retrieved from http://www.secp.gov.pk/news/pdf/news_09/cra_comite_bkgrnd.pdf

Sori, Z. M., \& Jalil, H. A. (2009). Financial ratios, discriminant analysis and the prediction of corporate 
distress. Journal of Money, Investment and Banking, 11, 5-15.

SPSS User Guide. IBM SPSS Statistics 20 Core System User's Guide, SPSS Inc.

Sung, T. K., Chang, N., \& Lee, G. (1999). Dynamics of modeling in data mining: Interpretive approach to bankruptcy prediction. Journal of Management Information System, 16(1), 63-85.

Tinoco, M. H., \& Wilson, N. (2013). Financial distress and bankruptcy prediction among listed companies using accounting, market and macroeconomic variables. International Review of Financial Analysis, 30(4), 394-419.

Ugurlu, M., \& Aksoy, H. (2006). Prediction of corporate financial distress in an emerging market: The case of Turkey. Cross Cultural Management: An International Journal, 13(4), 277-295.

Wang, Y., \& Campbell, M. (2010). Financial ratios and the prediction of bankruptcy: The Ohlson model applied to Chinese publicly traded companies. The Journal of Organizational Leadership $\mathscr{E}$ Business, 17(1), 1-15.

Westgaard, S. \& Wijst, N. V. (2001). Default probabilities in a bank portfolio: A logistic model approach. European Journal of Operational Research, 135(2), 338-349.

Yang, Z., Platt, M., \& Platt, H. (1999). Probabilistic neural networks in bankruptcy prediction. Journal of Business Research, 44(2), 67-74.

Zeitun, R., Tian, G., \& Keen, S. (2007). Default probability for the Jordanian companies: A test of cash Dow theory. International Research Journal of Finance and Economics, 8, 147-62

Zhang, L., Altman, E. I., \& Yen, J. (2010). Corporate financial distress diagnosis model and application in credit rating for listing firms in China. Frontiers of Computer Science in China, 4(2), 220-236.

Zmijewski, M. (1984). Methodological issues related to the estimation of financial distress prediction models. Journal of Accounting Research, 22, 59-82. 
